\title{
Unique Polymict Breccia Xenolith from the Premier Mine: evidence of complex character of kimberlite formation processes
}

\author{
Nikolay P. Pokhilenko \\ V.S.Sobolev Institute of Geology and Mineralogy, SB RAS, Novosibirsk, Russia
}

\section{Introduction}

Very rare xenoliths of so-called "polymict peridotites" firstly described for the South African kimberlites of Mesozoic age of emplacement (Lawless et al., 1979) belong to the most interesting and important material for the reconstruction of nature and features of the kimberlite formation processes. A xenoliths of this type were also found in Siberian kimberlites of Middle Paleozoic age (Pokhilenko, Sobolev, 1978; Lazko et al., 1983). The polymict breccia xenolith from Premier Mine $(14 \times 9 \times 4 \mathrm{~cm})$ described in this paper is the first find of this kind in kimberlite of Precambrian age. It composed by megacrysts and xenocrysts of ilmenite, garnet, pyroxenes, olivine, rare fragments of upper mantle peridotites (near $80 \mathrm{vol} . \%$ ) and cementing mass composed by serpophyte developed after fine-grained quenched products of primary cementing mass, phlogopite, ilmenite, rutile and rare grains of carbonate was studied. Unlike the xenoliths of polymict peridotite from Mesozoic kimberlites (Lawless et al., 1979) cementing mass of that xenolith does not contain sulphides at all. There are four relatively big fragments (up to $2 \mathrm{~cm}$ ) of peridotites on the xenolith surface. Coexisting olivine and OPX were found in three of them and olivine+OPX + Cr-pyrope in single fragment.

\section{Mineral chemistry}

Olivine occurs in fragments of peridotites and as xenocrysts up to $4 \mathrm{~mm}$ in size, and its amount is significantly less than in previously described xenoliths of polymict peridotites (Pokhilenko, Sobolev, 1978; Lawless et al., 1979). The Mg \# variation is 90.0-92.6 that is considerably narrow than one for polymict peridotites from Bultfontain and DeBeers Mines. NiO and $\mathrm{Cr}_{2} \mathrm{O}_{3}$ contents vary in intervals $0.35-0.40$ and 0.04-0.05 wt.\%, respectively.

Orthopyroxene grains (up to $14 \mathrm{~mm}$ ) have sings of resorption on contact with quenched material of cementing mass. They can be divided into two groups on the base of their composition: 1) high-Mg with elevated $\mathrm{Cr}$-content ( $\mathrm{Mg} \#>90 ; \mathrm{Cr}_{2} \mathrm{O}_{3}>0.15$ wt.\%); 2) more Fe-rich with insignificant admixture of $\mathrm{Cr}(\mathrm{Mg \#}$ $<88 ; \mathrm{Cr}_{2} \mathrm{O}_{3}<0.03$ wt.\%). The second group has a composition features typical of OPXes of megacrysts suite. All the analyzed OPXes have relatively high $\mathrm{CaO}$ content (1.07-1.36 wt.\%) reflecting their high-T origin. $\mathrm{Na}_{2} \mathrm{O}$ content varies from 0.20 to 0.47 wt. $\%$.

Garnet grains are variable in sizes (up to $12 \mathrm{~mm}$ ), morphology, color (yellow, orange, red, purple, mauve, and dark-colored grains with strong alexandritic effect) and all the grains have not keliphite rim. Rare grains of mauve grains have relics of yellow-orange rim. It is possible to divide at least 5 genetic types of garnets in studied sample belonging to: 1) megacryst suite ( $\mathrm{Mg \#}$ $=70-82 ; \mathrm{TiO}_{2}=1.00-1.27$ wt. $\% ; \mathrm{Cr}_{2} \mathrm{O}_{3}=0.06-2.00$ wt. $\%$; $\mathrm{Na}_{2} \mathrm{O}=0.11-0.18$ wt. $\%$; Ti/Cr=0.5-15.8); 2) high-T sheared peridotites $(\mathrm{Mg} \#=79-86 ; \quad \mathrm{Cr} 2 \mathrm{O} 3=1.26-2.90$ wt. $\% ; \quad \mathrm{TiO}_{2}=0.63-1.33$ wt. $\left.\% ; \quad \mathrm{Ti} / \mathrm{Cr}=0.43-0.65\right) ; 3$ ) deformed and metasomatized moderate- $\mathrm{T}$ lherzolites (Mg\#=85-86; $\mathrm{TiO}_{2}=0.2-1.1$ wt.\%; $\mathrm{Cr}_{2} \mathrm{O}_{3}>2$ wt.\%). 4) depleted peridotites including subcalcic high-Cr pyrope harzburgites $\quad\left(\mathrm{Mg} \#=83-88 ; \quad \mathrm{TiO}_{2}=0.01-0.18\right.$ wt.\%; $\mathrm{Cr}_{2} \mathrm{O}_{3}=2.5-11.7$ wt.\%); 5) eclogites (yellow and orange garnets enriched in $\mathrm{Fe}$ and $\mathrm{Ca}$, some of them have high admixture of $\mathrm{Na}_{2} \mathrm{O}-$ up to $0.21 \mathrm{wt} / \%$, indicating their high-T origin (Sobolev, Lavrentiev, 1971; McCandless, Gurney, 1989).
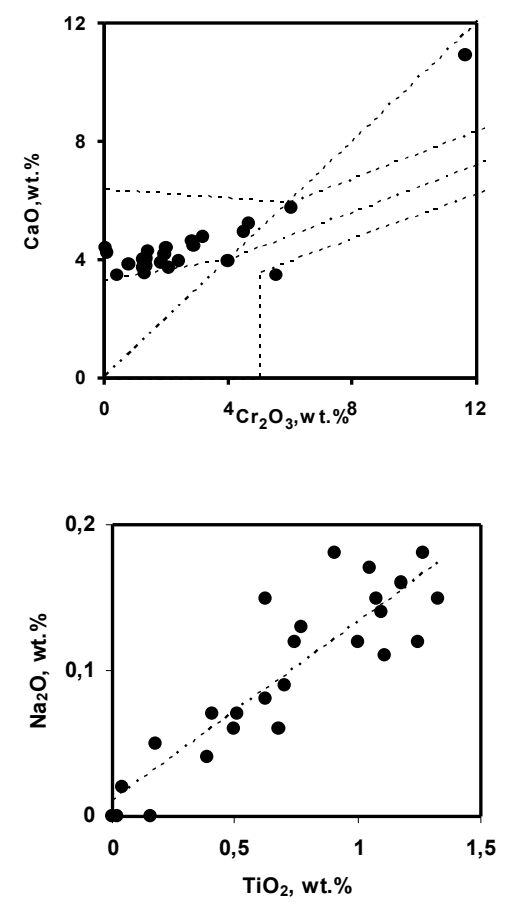

Fig 1. $\mathrm{Cr}_{2} \mathrm{O}_{3}$ vs $\mathrm{CaO}$ and $\mathrm{TiO}_{2}$ vs $\mathrm{Na}_{2} \mathrm{O}$ plots for pyrope garnets from sample FRB 1318. 
Clinopyroxene grains up to $25 \mathrm{~mm}$ in size belong to at least 3 genetic groups: 1) relatively low- $\mathrm{Mg}(\mathrm{Mg} \#=82-$ 84) subcalcic $(\mathrm{Ca} /(\mathrm{Ca}+\mathrm{Mg})=32-34 \%)$ high- $\mathrm{T}$ CPXes of megacryst suite, and there are not any signs of presence of OPX exsolved from high-T CPX grains as it was described for high-T CPXes from xenoliths of polymict breccias from Bultfontain and DeBeers Mines (Lawless et al., 1979); 2) more magnesian (Mg\#=89-90) subcalcic $(\mathrm{Ca} /(\mathrm{Ca}+\mathrm{Mg})=32-37 \%$ CPXes from high- $\mathrm{T}$ sheared peridotites; 3) relatively low-T $(\mathrm{Ca} /(\mathrm{Ca}+\mathrm{Mg})=43-48 \%) \mathrm{CPX}$ es from garnet peridotites. There are not any grain among the analyzed CPXes having excess of $\mathrm{Cr}+\mathrm{Al}$ value as compared with amount of $\mathrm{Na}$ that is the evidence of absence any significant amounts of AlIV in these CPXes.

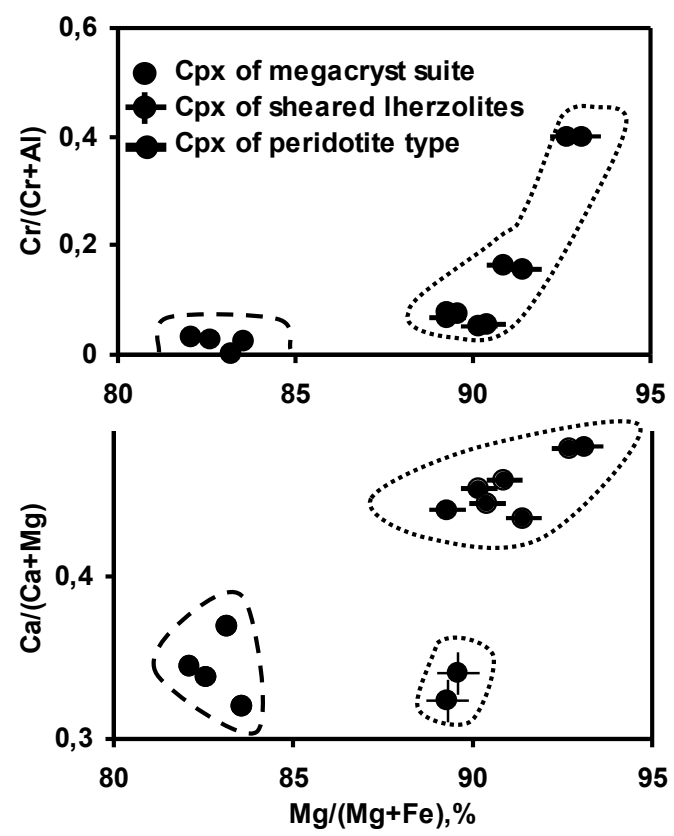

Fig 2. $100 \mathrm{Mg} /(\mathrm{Mg}+\mathrm{Fe}) \quad$ vs $\mathrm{Cr} /(\mathrm{Cr}+\mathrm{Al})$ and $100 \mathrm{Mg} /(\mathrm{Mg}+\mathrm{Fe})$ vs $\mathrm{Ca} /(\mathrm{Ca}+\mathrm{Mg})$ plots for cpx grains from sample FRB 1318.

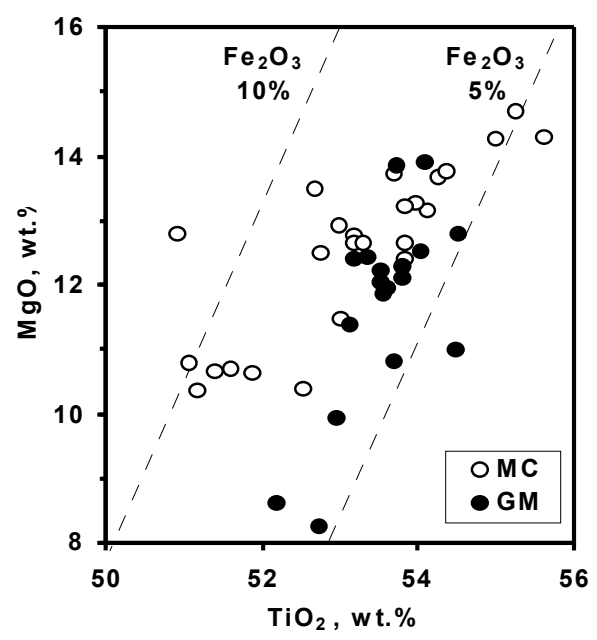

Fig 3. $\mathrm{TiO}_{2}$ vs $\mathrm{MgO}$ plot for ilmenite grains from sample FRB 1318 (MC - macrocrysts; GM microcrysts of groundmass)
Ilmenite occurs as large xenocrysts (up to $27 \mathrm{~mm}$ ) and fine grains $(0.05-0.4 \mathrm{~mm})$ in cementing mass. For large grains composition variations are: $\mathrm{MgO}=8.25-14.7$ wt. $\%, \mathrm{Cr}_{2} \mathrm{O}_{3}=0.60-2.07$ wt.\%, and they have high $\mathrm{Al}_{2} \mathrm{O}_{3}$ content (0.75-2.07 wt.\%). Fine-grained ilmenite of cementing mass has in average less $\mathrm{MgO}$ and $\mathrm{Cr}_{2} \mathrm{O}_{3}$, and higher in average $\mathrm{Al}_{2} \mathrm{O}_{3}$ (up to $2.12 \mathrm{wt}$., what is unusually high for kimberlite ilmenites).
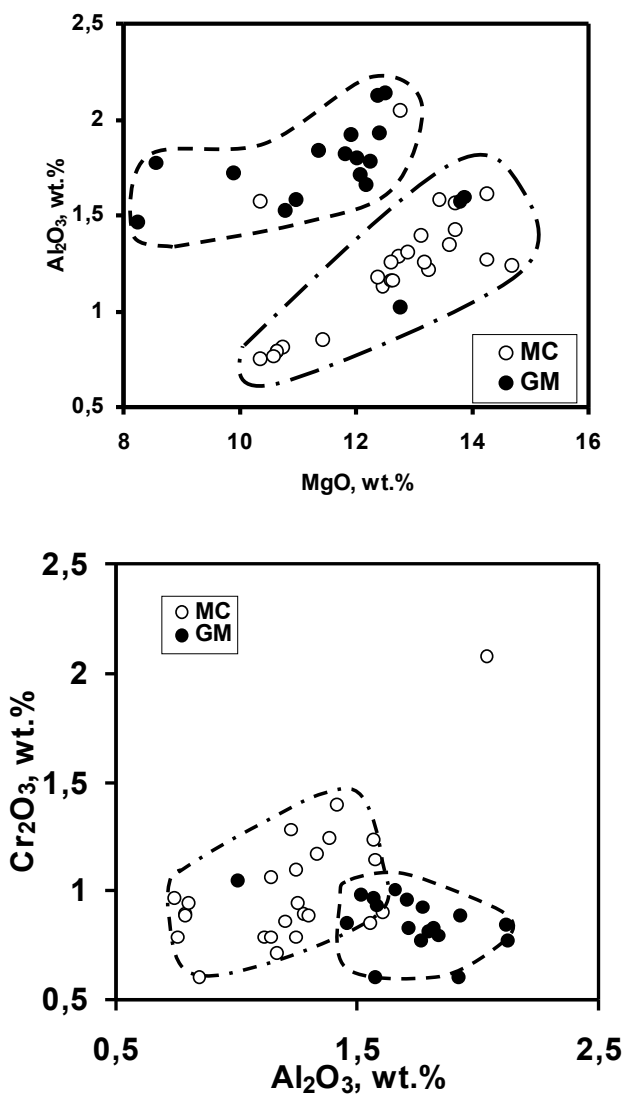

Fig 4. $\mathrm{MgO}$ vs $\mathrm{Al}_{2} \mathrm{O}_{3}$ and $\mathrm{Al}_{2} \mathrm{O}_{3}$ vs $\mathrm{Cr}_{2} \mathrm{O}_{3}$ plots for ilmenites of sample FRB 1318.

\section{Discussion}

The studied xenolith contains practically whole range of main kimberlite minerals of mantle origin. There are a significant differences between ordinary kimberlite and the studied rock: a) xenogenic matter/cementing mass and upper mantle matter/whole rock volume ratios for polymict breccia are much higher if compare with ordinary kimberlite; b) very high proportion of xenocrysts of megacryst suite; c) absence of upper mantle material of relatively small depth $(<100 \mathrm{~km})$ as well as absence of material of crustal origin in studied rock. The main features of studied xenoliths of polymict breccias are: a) clear sings of plastic and fracture deformation of some fragments of these rocks, such as milling, crushing and mixing; b) presence of variable amounts (from traces up to $20 \mathrm{vol}$. \%) of formerly liquid phase (quenched, partially crystallized, metasomatized or altered) origin of which is enough vague and deserving of separate study and discussion; c) extremally disequilibrated character of populations of mineral phases of the xenocrysts suite of these rocks 
and the signs of development in variable scale of processes of re-equilibration such as exsolution of high temperature pyroxenes, growth of external zones of similar composition on the cores of the same named minerals having very wide variations in composition. Essential interest presents the estimation of interval of depths of formation of the separate fragments composing the studied xenolith. Using for an approximate estimation of $\mathrm{T}$ of equilibrium of studied CPXes the diopside solvus (Davis, Boyd, 1966) we obtain T interval $\sim 950-1400^{\circ} \mathrm{C}$, and using the geotherm for lithospheric mantle of this area (Danchin, 1979) it is possible to estimate that the depth interval corresponding to this temperature interval is from 120130 to $210-220 \mathrm{~km}$.

Of special importance are a clear sings of significantly different degree of deformation of separated fragments of rocks and xenocrysts composed of polymict breccias. This feature give the base to suppose that the processes of deformation were developed mainly before the appearance of significant amounts of liquid material which was in the first a peculiar lubricant, and in the second, in the great degree impeded the appearance of stress pressure in its presence, which is necessary for development of plastic and fracture deformations. It is likely that initial process of partial melting producing the first portion of "lubricating" melt material was related with the depths of the fertile megacrists suite rocks formation. This conclusion can be supported by: a) presence of high proportion of fragments of these megacrysts in polymict breccias; b) presence of significant amounts of fine-grained ilmenite and phlogopite in quenched material of cementing mass. This melt provided the possibility: a) of very intensive process of squeezing out of this complex material composed by predominating solid matter and relatively small amount $(\sim 20-30$ vol.\%) of melt material on the shallower levels of upper mantle inside the limits of vertical dynamically active zones; b) a progressive contamination of this moving upward substance by disintegrated material of upper levels of lithospheric mantle. What about the studied xenolit of polimict breccia from the Premier Mine the scale of interval of such vertical movement of this complex material from the bottom of lithosphere upward was at leas near $100 \mathrm{~km}$. This movement was accompanied by intensive processes of mixing and contamination by new solid upper mantle material of shallower origin.

A comparative analysis of all obtained data allow us to propose that it is most probably that the studied polymict breccia formation as well as formation of similar rocks from Mesozoic kimberlites of South Africa and Paleozoic kimberlites of Siberia was directly related to initial stage of kimberlite formation, and polymict breccias are the peculiar "underdeveloped embryo" of ordinary kimberlite reflecting beginning of dynamic and thermal activization of kimberlite-generating levels of the lithospheric mantle roots producing initial amounts of kimberlite melts (Pokhilenko et al., 1999; Agashev et al. 2006).

\section{Acnowlegements}

Author devotes this paper to the memory of Dr. F.R. "Joe" Boyd. This study was supported by Russian Foundation for Basic Research (Grant \# 07-05- 00345).

\section{References}

Agashev, A.M., Pokhilenko, N.P., Malkovets, V.G., Sobolev, N.V. 2006. Sm-Nd isotope system in the garnet megacrysts from the Udachnaya kimberlite pipe, Yakutia and petrogenesis of kimberlites . Doklady Earth Sciences, 407a (3), 491-494.

Danchin, R.V., 1979. Mineral and bulk chemistry of garnet lherzolite and garnet garzburgite xenoliths from the Premier Mine, South Africa. In: The Mantle Sample: Inclusions in Kimberlites and Other Volcanics. F.R. Boyd, H.O.A. Meyer, Eds., AGU, Washington, 104122.

Davis, B.T.C., Boyd, F.R., 1966. The join $\mathrm{Mg}_{2} \mathrm{Si}_{2} \mathrm{O}_{6}$ $\mathrm{CaMgSi}_{2} \mathrm{O}_{6}$ at $30 \mathrm{~kb}$ pressure and its application to pyroxenes from kimberlites. Journal Geophysical Research, 71, 3567-3576.

Lawless, P.J., Gurney, J.J., Dawson, J.B., 1979. Polymict peridotites from the Bultfontain and DeBeers Mines, Kimberley, South Africa. In: The Mantle Sample: Inclusions in Kimberlites and Other Volcanics. F.R. Boyd, H.O.A. Meyer, Eds., AGU, Washington, 145155.

Lazko, E.E., Serenko, V.P., Muravitsrfya, G.N., 1983. Sheared peridotite with the garnet of varying composition from the Udachnaya kimberlite pipe. Doklady Ac. Sci. USSR, 268 (6), 1458-1462 (in Russian).

McCandless, T.E., Gurney, J.J., 1989. Sodium in garnet and potassium in clinopyroxene: criteria for classifying of mantle eclogites. In: Kimberlites and Related Rocks, 2. J. Ross et al., Eds. Blackwell, Melbourn, 827-832.

Pokhilenko, N.P., Sobolev, N.V., 1978. The garnets of different composition in the sample of sheared lherzoliute from the Udachnaya kimberlite pipe. In; Abstract Volume of the 11th Meeting of IMA, 11, Novosibirsk, 9.

Pokhilenko N.P., Sobolev, N.V., Kuligin, S.S., Shimizu, N., 1999. Peculiarities of distribution of pyroxenite paragenesis garnet in Yakutian kimberlites and some aspects of the evolution of the Siberian craton lithospheric mantle. In: Proceedings of the $7^{\text {th }}$ International Kimberlite Conference, Nixon Volume, Cape Town, 689-698.

Sobolev, N.V., Lavrentiev, Yu. G., 1971. Isomorphic sodium admixture in garnets formed at high pressures. Contributions to Mineralogy and Petrology, 31, 1-12. 